\title{
Znaczenie receptora progesteronowego w luminalnych rakach piersi
}

\author{
Wojciech Kuncman, Marcin Braun, Radzisław Kordek
}

W praktyce klinicznej raki piersi luminalne B utożsamiane są z posiadającymi receptor estrogenowy, brakiem receptora HER2 oraz z brakiem lub niskimi poziomami receptora progesteronowego, ewentualnie z wysokim indeksem Ki67. Rzeczywista klasyfikacja molekularna raków piersi jest oparta o różnice w ekspresji całego panelu genów, nie tylko związanych z powyższymi receptorami, jednak dla celów klinicznych przyjęto uproszczony podział. Raki typu luminalnego $B$ to w klasyfikacji klinicznej raki z ekspresją ER, jednak z gorszym rokowaniem. Coraz częściej w piśmiennictwie sugeruje się, że raki luminalne $B$ stanowią grupę, w której aktywacja receptora estrogenowego nie jest kluczowa, a "siłą napędową" nowotworu są inne szlaki czynników wzrostu, związane na przykład z nabłonkowym czynnikiem wzrostu (EGF), insulinopodobnym czynnikiem wzrostu (IGF) czy czynnikiem wzrostu fibroblastów (FGF). Złożoności dodają liczne interakcje różnych czynników wzrostu z innymi receptorami. Przedstawione w tym artykule rozważania są podstawą do pełniejszego zrozumienia heterogenności raka piersi oraz są punktem wyjścia do dalszego pogłębiania wiedzy na ten temat.

\section{Role of progesterone receptor in luminal breast cancers}

In clinical practice luminal B breast tumours are characterised by having estrogen receptor, the absence of HER2, and a lack or low levels of progesterone receptor, optionally with a high index of Ki67. However, the actual molecular classification of luminal cancers is based on differences in the expression of the whole panel of genes, not only those related to the above mentioned receptors. Luminal B cancers, are in fact, estrogen receptor positive tumours, but with worse outcome. Recently, it is frequently suggested that the luminal B tumours are a group in which the function of the estrogen receptor is not critical and other pathways are over-activated, which are related with growth factors: for example epithelial (EGF), insulin-like (IGF ) or fibroblast (FGF). Surprisingly there are also many interactions between various growth factors with estrogen receptor. This paper presents the heterogeneity of breast cancer. It is also a starting point for further research.

NOWOTWORY Journal of Oncology 2015; 65, 5: 383-388

Słowa kluczowe: rak piersi, luminalny, estrogenowy, progesteronowy, heterogenność, klasyfikacja molekularna, czynniki wzrostu

Key words: breast cancer, luminal, estrogen, progesterone, heterogeneity, molecular classification, growth factors

\section{Wstęp}

Oceniane immunohistochemicznie ekspresje receptorów dla estrogenu (ER), progesteronu (PR) i receptora HER2 są od lat standardami diagnostyki i predylekcji w raku piersi. Dzielą raki na podstawowe grupy: z ekspresją receptorów steroidowych (luminal-like), HER2-dodatnie oraz ne- gatywne dla tych trzech markerów. Klasyfikacja molekularna oparta na ekspresji genów w dużej mierze przekłada się na ten podział, nie jest jednakjego prostym odzwierciedleniem. Klasyfikacja molekularna, w odróżnieniu od klasyfikacji klinicznej, nie odnosi się tylko do ekspresji powyższych genów, ale do całego ich panelu. Cechą wyróżniającą raki luminalne 
jest przede wszystkim ekspresja cytokeratyn, typowych dla komórek światła przewodów (luminalnych) oraz ekspresja szeregu innych genów, bez konieczności ekspresji ER [1-3]. Podtyp luminalny A ma zazwyczaj silną ekspresję genów związanych z aktywnością ER, natomiast podtyp luminalny $B$ różni się nie tylko słabszą ekspresją ER i PR (lub jej brakiem), ale także odmiennym profilem ekspresji szeregu innych genów. W rakach luminalnych $B$, pomimo ekspresji $E R$, inne geny związane $z$ aktywnością tego receptora nie wykazują tak silnej aktywności jak w luminalnych A. Zazwyczaj też brak jest ekspresji PR, która z kolei jest bardzo duża w rakach luminalnych A [4]. Wydaje się zatem, co jest sugerowane w piśmiennictwie, że raki luminalne $B$ stanowią grupę, w której aktywacja ER nie pełni istotnej roli, a nowotwór jest „napędzany" innymi mechanizmami komórkowymi, przede wszystkim czynnikami wzrostu (EGF, FGF, IGF itp.) [3].

\section{Raki luminalne a receptor estrogenowy}

Raki luminalne posiadają ekspresję ER, jednak w różnym odsetku komórek i z różną się intensywnością. Proste przenoszenie siły ekspresji na biologię nie jest takie oczywiste, ponieważ w zdrowym sutku tylko ok. 30\% luminalnych komórek wykazuje ekspresję ER i to nie te komórki proliferują [5]. Proliferują natomiast komórki sąsiadujące po uzyskaniu sygnału od komórek ER+ (w mechanizmie parakrynnym), a alternatywnym wyjaśnieniem jest utrata ekspresji receptora estrogenowego w komórkach ER+, po przyłączeniu liganda. Pokazuje to, jak trudno interpretować i porównywać obserwacje różnych raków piersi, ponieważ prawdopodobnie mamy tu do czynienia z kilkoma równoległymi mechanizmami.

Leczenie hormonalne antyestrogenowe jest stosowane w rakach piersi przy każdej ekspresji ER, chociaż odsetek odpowiedzi jest związany z intensywnością ekspresji [6]. Silna ekspresja daje duże prawdopodobieństwo odpowiedzi, jednak nawet 1\% komórek z ekspresją ER daje nadzieję na skuteczność leczenia, co przekłada się na zalecenia terapeutyczne $[7,8]$.

W trakcie terapii hormonalnej część raków traci ekspresję ER. W jednej z prac aż 33,6\% chorych utraciło ekspresję ER i te chore miały zwiększone ryzyko zgonu aż o 48\% [9]. Te dwie informacje przypominają o heterogenności raków i uproszczonym spojrzeniu na to zagadnienie. Jak widać, mała część populacji komórek z ekspresją ER może być istotna dla wzrostu raka, a silna ekspresja w licznych komórkach może mieć małe znaczenie w przypadku, gdy w czasie terapii hormonalnej przewagę uzyskują klony niezależne od ER, których wzrost opiera się na innych czynnikach wzrostu. Prawdopodobnie też w części raków ER(+) receptor estrogenowy, mimo iż obecny, nie jest istotnym „silnikiem" wzrostu komórek raka, który jest już napędzany innymi czynnikami wzrostu [10].
Jak wspomniano, raki luminalne charakteryzują się określonym profilem ekspresji genów, zazwyczaj z silną ekspresją ER. Nie znaczy to jednak, że jest to zasadą, ponieważ kilka procent raków luminalnych nie wykazuje immunohistochemicznej ekspresji ER [4]. Podobnie jest w innych podtypach - ekspresja ER pojawia się nawet w rakach typu podstawnego (w klasyfikacji molekularnej). Nie można zatem $w$ bezpośredni sposób utożsamiać raków luminalnych z obecnością receptora estrogenowego, w praktyce klinicznej obserwujemy jednak uproszczenie: gdzie raki luminalne są utożsamiane $z$ rakami ER+.

\section{Raki luminalne B - niejasności nomenklaturowe}

W klasyfikacji St. Gallen, jak i w zaleceniach ESMO określa się dosłownie raki luminalne B jako ER+, HER2- oraz z niską ekspresją PR lub wysokim indeksem Ki67 [8]. Zdaniem znawców tematu jest to niewłaściwe uproszczenie, i takie raki powinno się nazywać ",podobnymi do luminalnych $\mathrm{B}^{\prime}$ — „Iuminal B-like" (LB-L) [8].Z tych powodów określenie raki „luminalne B" powinno pozostawać tylko dla raków, gdzie określono ekspresję genów metodami molekularnymi, a raki LB-L to grupa raków z gorszym rokowaniem. Wydzielenie tak rozumianych raków LB-L na podstawie niskiej ekspresji PR lub wysokiego indeksu Ki67 znajduje rosnące uzasadnienie w piśmiennictwie, a niska ekspresja PR staje się ważnym złym czynnikiem rokowniczym [10-13].

Ponieważ raki luminalne $B$ charakteryzują się gorszym rokowaniem niż luminalne $A$, a jednocześnie niezależnym, ważnym czynnikiem rokowniczym jest aktywność proliferacyjna mierzona ekspresją antygenu Ki67, w zaleceniach pojawiło się uproszczenie kwalifikujące raki do grupy raków luminalnych $B$, przy określonym odsetku komórek dodatnich. Co prawda, raki luminalne A mają średni indeks Ki67 niższy niż luminalne B (1-29\%) [14, 15], ale to nie znaczy, że Ki67 rozróżnia te typy, są to bowiem zbiory jedynie częściowo zachodzące na siebie. Kwalifikacja Ki67 stała się standardem diagnostycznym, jednak powtarzalność tej metody jest krytykowana i nawet dychotomiczny podział (niski Ki67 - wysoki Ki67) daje ponad 20\% błędów [16]. Trudno zatem o ustalenie jednoznacznego granicznego indeksu Ki67, przy którym należy zmienić klasyfikację do terapii uzupełniającej. Można przyjąć, że „wysoki Ki67" to około $20 \%$ i więcej komórek $[8,16]$. Warto też podkreślić, że wysoki Ki67 ma wartość rokowniczą — tak jak wiele czynników badanych w nowotworach, a nie jest wskaźnikiem osiągnięcia zysku z terapii. Jest to więc czynnik prognostyczny, a nie predykcyjny.

Jeżeli wysoki indeks Ki67 wiąże się z fenotypem raków LB-L i zarazem niska ekspresja PR jest cechą raków z tej grupy, wydaje się, że może wystarczy oceniać ekspresję PR w miejsce Ki67. Wyniki nie są jednak jednoznaczne, ponieważ okazało się, że w badaniach molekularnych ekspresja 
Ki67 jest bardzo słabo skorelowana ze słabą ekspresją PR i że są to czynniki niezależne [4]. Jednak odmienne wyniki uzyskano w badaniach immunohistochemicznych, bliższych praktyce klinicznej, gdzie wysoki indeks Ki67 korelował z niską ekspresją PR w rakach ER+ [17]. Problem utożsamiania wyników dwoma różnymi technikami badania ekspresji genów często pojawia się w piśmiennictwie dotyczącym raka piersi. Pozorna logika nakazuje, aby te wyniki pokrywały się ze sobą, tymczasem ilość mRNA oraz ilość białka oznaczana immunohistochemicznie bywają różne. Bierze się to z dwóch przyczyn: przyjęcia „punktu odcięcia" dla ekspresji mRNA oraz ze stosunku ilości komórek nowotworowych i innych komórek towarzyszących w badanej tkance. Jeżeli liczba komórek raka ER+ będzie niska, wynik badania mRNA może być negatywny $[18,19]$, natomiast przy dużej liczbie towarzyszących ER-dodatnich komórek prawidłowego miąższu sutka można uzyskać dodatni wynik ekspresji mRNA w raku ER-. Podobne problemy występują w przypadku Ki67, gdzie antygen może być produkowany przez komórki inne niż nabłonkowe (zapalne, podścieliska itp.). Obecnie, zgodnie z zaleceniami terapeutycznymi, ocena ER i PR powinna być przeprowadzana immunohistochemicznie, a badania naukowe powinny wyraźnie oddzielać te dwie metody oceny. Ostatnio zaproponowano rozszerzenie panelu markerów definiującego raki „podobne do luminalnych B" (LB-L) o P53 [20] i dopiero wzięcie pod uwagę tych trzech elementów - wysokiego Ki67 (w tej pracy ponad 14\%), ekspresji P53 i ekspresji PR - wydzielało grupę raków ER+ o gorszym rokowaniu.

\section{Receptor estrogenowy i estrogen jako elementy bardziej skomplikowanego układu}

Receptor estrogenowy działa w dwóch podstawowych mechanizmach — błonowym i jądrowym, przy czym każdy z nich jest wieloskładnikowy i złożony $[10,21]$ oraz może być skutkiem zdarzeń niezwiązanych z estrogenami [10]. Mechanizm błonowy nie wymaga produkowania białek, jest natychmiastowy po stymulacji estrogenami i wyraża się aktywacją szlaków sygnałowych zbliżonych do błonowych receptorów czynników wzrostu, między innymi fosforylacją Akt [21]. Co więcej, opisano także tego typu reakcje po stymulacji estrogenami w komórkach pozbawionych ER [22]. Jednym z proponowanych mechanizmów tego działania jest współdziałanie ze szlakiem insulinopodobnego czynnika wzrostu — IGF [23]. Interakcje te są bardzo liczne: IGF może aktywować ER przy braku estrogenów, estrogeny mogą zwiększać ekspresję IGF1R i jego powinowactwo do IGF1 [10]. Błonowy ER może także aktywować szlaki efektorowe niektórych naskórkowych czynników wzrostu (EGF-EGFR-PI3K) [10]. Co ciekawe, ten mechanizm jest indukowany nie tylko przez estrogeny, ale także przez tamoksyfen [24].

Mechanizm jądrowy działania ER również staje się coraz bardziej złożony. Pierwotne założenie, że ER po aktywacji estrogenami podąża do jądra, gdzie działa jako czynnik transkrypcyjny indukujący produkcję wielu białek, okazuje się prawdziwe, ale niepełne. ER może być podobnie aktywowany przez inne ligandy, m.in. EGF, IGF czyTGF, może też być fosforylowany bezpośrednio, bez liganda, m.in. przez ERK czy Akt [10]. Ta orkiestra jest regulowana przez liczne białka aktywujące lub hamujące, na przykład reakcja komórki na tamoksyfen (aktywacja lub blokowanie ER) zależy od tych elementów regulujących [10].

Jak widać, ER jest powiązany licznymi relacjami ze szlakami przekazywania sygnału i aktywnością czynników wzrostu i ich receptorów (EGFR, IGF1R). Te sieci powiązań mogą powodować uniezależnienie się od klasycznej reakcji estrogen-ER przy aktywacji równoległych szlaków. Wykazano na liniach komórek raka piersi, że duża aktywność IGF1R po związaniu IGF1 prowadzi do oporności na hamowanie wzrostu przez antyestrogeny [25].

\section{Receptor progesteronowy — ważny biologicznie marker raka piersi}

Przez wiele lat nie rozróżniano odmiennego znaczenia biologicznego i klinicznego ER i PR. Wychodzono z prostego założenia, że ER indukuje ekspresję PR, więc są one $z$ sobą tożsame. Słabą ekspresję PR, lub jej brak, tłumaczono najczęściej problemami technicznymi. Badania profili molekularnych wykazały jednak, że raki ER+/PR-istnieją i stanowią odmienną grupę, różniącą się ekspresją całych zestawów genów [3 niepublikowane obserwacje własne]. Na odmienność kliniczną raków ER+/PR- wskazuje obserwacja, że raki ER+/PR- charakteryzują się odmiennymi od raków ER+/ /PR+ czynnikami ryzyka i epidemiologią, występując m.in. u starszych osób [10, 26-28]. Raki ER+/PR- w porównaniu z ER+/PR+ częściej występują u starszych chorych, częściej są aneuploidne, dużo częściej mają ekspresję EGFR (25\% względem 8\%) i HER2 (21\% względem 14\%) [28]. Leczenie tamoksyfenem było mniej skuteczne u chorych z nadekspresją EGFR i HER2, ale tylko w grupie ER+/PR-, podczas gdy w grupie ER+/PR+ nie zaobserwowano takiej zależności. Widać zatem, że brak ekspresji PR może świadczyć o aktywności szlaków sygnałowych innych czynników wzrostu.

Wydaje się także, że taki fenotyp z brakiem ekspresji PR wiąże się z przynależnością do grupy raków luminalnych $B$ i z ograniczoną odpowiedzią na leczenie hormonalne [10]. Jednak ta odpowiedź jest uzależniona od stosowanego leku - gorsze rokowanie w grupie ER+/PR- było widoczne po tamoksyfenie, lecz nieznacznie zmieniało się po anastrozolu $[10,29]$. Ta zagadkowa reakcja wskazuje, że mechanizm nie jest prosty i oczywisty: blokowanie syntezy estrogenów daje lepszy efekt od blokowania receptora. Estrogeny mogą zatem aktywować inne szlaki czynników wzrostu niż ER.

\section{Receptor progesteronowy a rak piersi}

Związek pomiędzy liczbą ciąż, karmieniem piersią czy też liczbą cykli miesięcznych a ryzykiem zachorowania na 
raka piersi rodzi pytanie o potencjalną rolę progesteronu w rozwoju raka [27]. W drugiej fazie cyklu miesięcznego progesteron indukuje proliferację końcowych części przewodów piersiowych, ich rozgałęzianie się oraz tworzenie się nowych pęcherzyków, przygotowując gruczoł do laktacji, działa zatem jako czynnik wzrostu [30].

Istotne informacje o potencjalnym związku progesteronu i jego analogów z ryzykiem raka piersi wnoszą analizy skutków wieloletniej hormonoterapii zastępczej (HTZ), gdzie zaobserwowano zwiększoną zachorowalność [31, 32]. Stosowanie samego estrogenu tylko nieznacznie wpływało na częstość raka, a nawet w niektórych obserwacjach ją zmniejszało [33-36]. Okazuje się zatem, że to gestageny - drugi składnik HTZ - są zapewne odpowiedzialne za wzrost ryzyka raka piersi.

Zaskakujące wyniki przyniosła publikacja porównująca poszczególne analogi progesteronu stosowane w HZT. Największy, aż 69-procentowy wzrost ryzyka zachorowania zaobserwowano po zastosowaniu estrogenu z dedrogesteronem $[37,38]$. Poszukując przyczyn tych zmienności, zaobserwowano, że analogi progesteronu charakteryzuje dłuższy okres półtrwania, co może mieć związek z ryzykiem raka [39, 40]. Kolejną przyczyną może być możliwość odziaływania na inne receptory steroidowe - glikokortykosteroidowe oraz androgenowe, co może być współistniejącym czynnikiem pobudzającym komórki luminalne [41].

Doustna antykoncepcja hormonalna, która również zawiera gestageny, nieznacznie zwiększa ryzyko zachorowania na raka piersi po okresie 10 lat od stosowania, głównie dla raków ER+ $[42,43]$. Także $w$ tym przypadku estrogeny mają drugorzędne znaczenie, ponieważ tabletki zawierające jedynie estrogen w małych dawkach (mini pills - POP) nie powodowały zwiększonej zachorowalności [44].

Niejednoznaczne są związki ryzyka raka piersi z ciążami, w trakcie których występuje długotrwały wzrost poziomu progesteronu. W trakcie samej ciąży oraz w ciągu kilku lat po jej zakończeniu obserwowano podwyższone prawdopodobieństwo wystąpienia raka, jednak liczba ciąż jest związana z mniejszym ryzykiem raka piersi [45]. Mechanizm tych różnic nie został w jednoznaczny sposób wyjaśniony — prawdopodobnie nie jest on jednoczynnikowy.

\section{Receptor progesteronowy i RANKL}

Receptor progesteronowy działa w dwóch głównych mechanizmach - wewnątrzkomórkowym i parakrynnym. W pierwszym - po aktywacji następuje aktywacja proliferacji, głównie na drodze ekspresji cykliny D1 [46]. Jednak komórki nieposiadające PR również mogą zostać aktywowane parakrynnie przez RANKL, syntezowanym w komórkach PR+ [46]. RANKL (Receptor Activator for Nuclear Factor KB Ligand — ligand aktywatora receptora jądrowego czynnika $\mathrm{kB}$ ) należy do rodzinyTNF i bierze udział także w kilku innych procesach metabolicznych, m.in. występując na powierzchni osteoklastów, gdzie je aktywuje.W terapii chorób kości stosowane jest przeciwciało monoklonalne przeciw RANKL — denosunab.

Obecnie lek jest wykorzystywany m.in. u kobiet po menopauzie z wysokim prawdopodobieństwem złamań oraz w przypadku zapobiegania komplikacji u osób z przerzutami nowotworowymi do układu kostnego.

Wykazano na liniach komórkowych raka sutka, że aktywacja czynnika transkrypcyjnego NF-kB przez RANKL aktywuje proces przechodzenia epitelialno-mezenchymalnego (EMT) [47]. Teza, że w przypadkach PR-negatywnych proliferacja i EMT są indukowane przez inną drogę aktywacji RANKL (lub jego receptora — RANK), wydawała się interesująca. Niestety, ekspresja RANK w rakach piersi jest niższa niż w zdrowym sutku, a niższa ekspresja RANK lub RANKL wiąże się z gorszym rokowaniem w rakach piersi [48]. Wydaje się zatem, że ekspresja RANKL jest tylko PR-zależna i nie występuje tu alternatywny mechanizm aktywacji receptora RANK.

\section{Receptor progesteronowy wygaszany aktywnością innych szlaków dla czynników wzrostu?}

Jeżeli RANKL nie jest aktywowany w PR-negatywnych rakach piersi, to może PR jest „wygaszany" przez aktywność innych szlaków przekazywania sygnału, skutkujących fosforylacją tych samych białek efektorowych i włączaniem pętli zwrotnych, skutkujących brakiem ekspresji PR. W grę wchodzą przede wszystkim szlaki czynników wzrostu, z których wiele zachodzi na siebie i aktywuje te same białka efektorowe. I być może nawet przy ekspresji ER i obecności estrogenów aktywne równoległe szlaki czynników wzrostu aktywują kofaktory ER i hamują transkrypcję wielu związanych z ER genów, między innymi $P G R$.

Takie wnioski płyną m.in. z obserwacji dotyczących ekspresji PR i HER2 [10]. Raki HER2+ znacznie częściej nie wykazują ekspresji PR, a guzy ER+/PR- z kolei częściej mają nadeskpresję HER2 $[10,49]$. Co ciekawe, brak odpowiedzi na tamoksyfen u chorych z guzami ER+ i nadekspresją HER2 nie był związany z poziomem ER [50].

W innych badaniach wykazano, że raki piersi ER+/PRczęściej mają zwiększoną ekspresję EGFR i że odpowiedź na tamoksyfen również nie była związana z poziomem ER [28]. Podobne wyniki uzyskali Lam i wsp., gdzie w liniach komórek raka (MCF-7B) tamoksyfen, niezależnie od ekspresji receptora $E R$, zwiększał ekspresję ER, zmniejszając aktywność PI3K/Akt i ERK [51]. Co ciekawe, w linii MCF-7 (ER+, $\mathrm{Bcl}$ 2-low) tamoksyfen hamował IGF1R, podczas gdy w linii MCF-7B (ER+, BCl2 high) - aktywował ten receptor. Autorzy konkludują, że Bcl2 moduluje odpowiedź na estrogeny/antyestrogeny i może to mieć związek z obserwacją, że raki z dużą ekspresją Bcl2 wiążą się z lepszym rokowaniem. Podobnie Zhang i wsp. wykazali, że linia MCF-7 z nadekspresją IGF1R jest oporna na stosowane antyestrogeny i wiąże się z aktywnością MAPK/ERK i PI3K [25]. Nie dziwi zatem, że raki 
piersi z wysoką ekspresją IGF1R wiążą się z gorszym rokowaniem [52]. Autorzy sugerują konsekwentnie, że wysoka ekspresja IGF1R może wiązać się z opornością na antyestrogeny w rakach $\mathrm{ER}+$.

Podobne obserwacje jak dla IGF1R poczyniono dla EGFR [53]. Także FGFR1 posiada właściwości indukowania estrogenooporności, a jego aktywność powoduje supresję ekspresji PR [54]. Podobne obserwacje poczyniliśmy w badaniach nad FGFR2 [dane niepublikowane]. Z drugiej strony zaobserwowano w hodowli komórek raka także efekt odwrotny: FGF2 aktywowało PR nie zmniejszając jego ekspresji [55].

W tym kontekście warto powrócić do cytowanych wcześniej obserwacji: dlaczego w części raków LB-L lepsze efekty kliniczne przynosi hamowanie syntezy estrogenów, a nie blokowanie receptora tamoksyfenem. Otóż można wytworzyć tu kilka koncepcji. Estrogeny mogą nieswoiście aktywować receptory innych czynników wzrostu lub tamoksyfen nie w każdym przypadku raka musi działać jako silny antagonista.

\section{Podsumowanie}

Podsumowując, raki luminalne A to zapewne guzy ze stosunkowo niewielkimi zaburzeniami regulacji wzrostu, oparte w dużej mierze na aktywacji zespołu genów związanych z ER. Natomiast raki luminalne B - nadal z ekspresją $E R$, jednak $z$ bardziej nasilonymi zaburzeniami w szlakach innych czynników wzrostu, z brakiem ekspresji PR. Utrata ekspresji PR, przy zachowanej ekspresji ER, jest prawdopodobnie wtórnym efektem aktywacji innych szlaków dla czynników wzrostu. Liczne wzajemne interakcje tych szlaków, i to na różnych poziomach, sugerują trudności we wskazaniu dominującego mechanizmu w poszczególnych przypadkach.

Lista zastosowanych skrótów:

ER - receptor estrogenowy (estrogen receptor)

$\mathrm{PR}$ - receptor progesteronowy (progesterone receptor)

HER2 - receptor drugiego ludzkiego naskórkowego czynnika wzrostu (human epidermal growth factor receptor 2, CD340)

EGF - naskórkowy czynnik wzrostu (epidermal growth factor)

FGF - czynnik wzrostu fibroblastów (fibroblast growth factor)

IGF — insulinopodobny czynnik wzrostu (insulin-like growth factor)

LB-L - podobne do luminalnych B (luminal B-like)

TGF — transformujący czynnik wzrostu (ransforming growth factor)

RANKL - ligand aktywatora receptora jądrowego czynnika KB (Receptor Activator for Nuclear Factor KB Ligand)

$\mathrm{HTZ}$ - hormonoterapia zastępcza

TNF — czynnik martwicy nowotworu (tumor necrosis factor)
ETM — przechodzenie epitelialno-mezenchymalnego (epithelial-mesenchymal transition)

Konfliktu interesów: nie zgłoszono

Dr n. med. Wojciech Kuncman

Zakład Patologii Katedra Onkologii

Uniwersytetu Medycznego $w$ Łodzi

e-mail:wojciechkuncman@gmail.com

Otrzymano i przyjęto do druku: 6 lipca 2015 r.

\section{Piśmiennictwo}

1. Prat A, Perou CM. Deconstructing the molecular portraits of breast cancer. Mol Oncol 2011; 5: 5-23.

2. Prat $A$, Ellis MJ, Perou CM. Practical implications of gene-expression-based assays for breast oncologists. Nat Rev Clin Oncol 2011; 9: 48-57.

3. Creighton CJ.The molecular profile of luminal B breast cancer. Biologics 2012; 6: 289-97.

4. Prat A, Cheang MC, Martín M i wsp. Prognostic significance of progesterone receptor-positive tumor cells within immunohistochemically defined luminal A breast cancer. J Clin Oncol 2013; 31: 203-9.

5. Russo J, Ao X, Grill C i wsp. Pattern of distribution of cells positive for estrogen receptor alpha and progesterone receptor in relation to proliferating cells in the mammary gland. Breast Cancer Res Treat 1999; 53: 217-27.

6. Harvey JM, Clark GM, Osborne CK i wsp. Estrogen receptor status by immunohistochemistry is superior to the ligand-binding assay for predicting response to adjuvant endocrine therapy in breast cancer. J Clin Oncol 1999; 17: 1474-81.

7. Hammond ME, Hayes DF, Dowsett M i wsp. American Society of Clinical Oncology/College of American Pathologists guideline recommendations for immunohistochemical testing of estrogen and progesterone receptors in breast cancer. Arch Pathol Lab Med 2010; 134: e48-72.

8. Senkus E, Kyriakides S, Penault-Llorca F i wsp. Primary breast cancer: ESMO Clinical Practice Guidelines for diagnosis, treatment and follow-up. Ann Oncol 2013; 24 suppl. 6: vi7-23.

9. Lindström LS, Karlsson E, Wilking UM i wsp. Clinically used breast cancer markers such as estrogen receptor, progesterone receptor, and human epidermal growth factor receptor 2 are unstable throughout tumor progression. J Clin Oncol 2012; 30: 2601-8.

10. Cui X, Schiff R, Arpino G i wsp. Biology of progesterone receptor loss in breast cancer and its implications for endocrine therapy. J Clin Oncol 2005; 23: 7721-35.

11. Inic $Z$, Zegarac $M$, Inic $M$ i wsp Difference between luminal $A$ and luminal B subtypes according to Ki-67, tumor size, and progesterone receptor negativity providing prognostic information. Clin Med Insights Oncol 2014; 8: 107-11.

12. Sato K, Miyashita M, Ishida T i wsp. Prognostic significance of the progesterone receptor status in Ki67-high and -low Luminal B-like HER2-negative breast cancers. Breast Cancer 2014 [Epub ahead of print].

13. Maisonneuve $P$, Disalvatore $D$, Rotmensz N i wsp. Proposed new clinicopathological surrogate definitions of luminal $A$ and luminal B (HER2-negative) intrinsic breast cancer subtypes. Breast Cancer Res 2014; 16: R65.

14. Nishimura $R$, Osako $T$, Nishiyama $Y$ i wsp. Prognostic significance of $\mathrm{Ki}-67$ index value at the primary breast tumor in recurrent breast cancer. Mol Clin Oncol 2014; 2: 1062-68.

15. Sahebjam S, Aloyz R, Pilavdzic Di wsp. Ki 67 is a major, but not the sole determinant of oncotype dx recurrence score. Br JCancer 2011; 105: 1342-45.

16. Polley MY, Leung SC, McShane LM i wsp. An international Ki67 reproducibility study. J Nat/ Cancer Inst 2013; 105: 1897-1906.

17. Yanai A, Inoue N, Yagi T i wsp. Activation of mTOR/S6K But Not MAPK Pathways Might Be Associated With High Ki-67, ER(+), and HER2(-) Breast Cancer. Clin Breast Cancer 2015; 15: 197-203.

18. Kordek R, Potemski P, Kusinska R i wsp. Basal keratin expression in breast cancer by quantification of mRNA and by immunohistochemistry. J Exp Clin Cancer Res 2010; 29: 39.

19. Potemski P, Pluciennik E, Bednarek AK i wsp. Evaluation of oestrogen receptor expression in breast cancer by quantification of mRNA. Histopathology 2007; 51: 829-36.

20. Feeley LP, Mulligan AM, Pinnaduwage D i wsp. Distinguishing luminal breast cancer subtypes by Ki67, progesterone receptor or TP53 status provides prognostic information. Mod Pathol 2014; 27: 554-61. 
21. Nemere I, Pietras RJ, Blackmore PF. Membrane receptors for steroid hormones: signal transduction and physiological significance. J Cell Biochem 2003; 88: 438-45.

22. Tsai EM, Wang SC, Lee JN i wsp. Akt activation by estrogen in estrogen receptor-negative breast cancer cells. Cancer Research 2001; 61: 8390-92.

23. Lee AV, Jackson JG, Gooch JL i wsp. Enhancement of insulin-like growth factor signaling in human breast cancer: estrogen regulation of insulin receptor substrate-1 expression in vitro and in vivo. Mol Endocrinol 1999; 13: 787-96.

24. Razandi M, Alton G, Pedram A i wsp. Identification of a structural determinant necessary for the localization and function of estrogen receptor $\alpha$ at the plasma membrane. Mol Cell Biol 2003; 23: 1633-46.

25. Zhang $Y$, Moerkens $M$, Ramaiahgari $S$ i wsp. Elevated insulin-like growth factor 1 receptor signaling induces antiestrogen resistance through the MAPK/ERK and PI3K/Akt signaling routes. Breast Cancer Research 2011; 13: R52.

26. Anderson WF, Chatterjee N, Ershler WB i wsp. Estrogen receptor breast cancer phenotypes in the surveillance, epidemiology, and end results database. Breast Cancer Res Treat 2002; 76: 27-36.

27. Colditz GA, Rosner BA, Chen WY i wsp. Risk factors for breast cancer according to estrogen and progesterone receptor status. J Nat/ Cancer Inst 2004; 96: 218-28.

28. Arpino G, Weiss H, Lee AV i wsp. Estrogen receptor-positive, progesterone receptor-negative breast cancer: association with growth factor receptor expression and tamoxifen resistance. J Natl Cancer Inst 2005; 97: 1254-61.

29. Baum M, Buzdar A, Cuzick J i wsp. Anastrozole alone or in combination with tamoxifen versus tamoxifen alone for adjuvant treatment of postmenopausal women with early-stage breast cancer: results of the ATAC (arimidex, tamoxifen alone or in combination) trial efficacy and safety update analyses. Cancer 2003; 98: 1802-10.

30. LongacreTA, Bartow SA. A correlative morphologic study of human breast and endometrium in the menstrual cycle. Am J Surg Pathol 1986; 10: 382-93.

31. Beral V. Breast cancer and hormone-replacement therapy in the million women study. Lancet 2003; 362: 419-27.

32. Chlebowski RT, Kuller LH, Prentice RL i wsp. Breast cancer after use of estrogen plus progestin in postmenopausal women. $N$ Engl J Med 2009;360: 573-87.

33. Anderson GL, Chlebowski RT, Aragaki AK i wsp. Conjugated equine oestrogen and breast cancer incidence and mortality in postmenopausal women with hysterectomy: extended follow-up of the women's health initiative randomised placebo-controlled trial. Lancet Oncol 2012; 13: 476-86.

34. Chlebowski RT, Anderson GL, Gass M i wsp. Estrogen plus progestin and breast cancer incidence and mortality in postmenopausal women. JAMA 2010; 304: 1684-92.

35. Ross, Ronald K, Annlia Paganini-Hill, Peggy C. Wan, and Malcolm C. Pike. Effect of hormone replacement therapy on breast cancer risk: estrogen versus estrogen plus progestin. J Nat/ Cancer Inst 2000; 92: 328-332.

36. Gray S. Breast cancer and hormone-replacement therapy: the Million Women Study. Lancet 2003; 362: 1332.

37. Fournier A, Berrino F, Clavel-Chapelon F. Unequal risks for breast cancer associated with different hormone replacement therapies: results from the E3N cohort study. Breast Cancer Res Treat 2008; 107: 103-11.
38. Fournier A, Franco B, Riboli E i wsp Breast cancer risk in relation to different types of hormone replacement therapy in the E3N-EPIC cohort. Int J Cancer 2005; 114: 448-54.

39. Kaaks R, Berrino F, Key T i wsp. Serum sex steroids in premenopausal women and breast cancer risk within the European Prospective Investigation into Cancer and Nutrition (EPIC). J Nat Cancer Inst 2005; 97: 755-65.

40. Schernhammer ES, Sperati F, Razavi P i wsp. Endogenous sex steroids in premenopausal women and risk of breast cancer: the ORDET cohort. Breast Cancer Res 2013; 15: R46.

41. Sitruk-Ware R. Pharmacological profile of progestins. Maturitas 2004; 47: 277-83.

42. Hunter DJ, Colditz GA, Hankinson SE i wsp. Oral contraceptive use and breast cancer: a prospective study of young women. Cancer Epidemiol Biomarkers \& Prevention. 2010; 19: 2496-2502.

43. Collaborative Group on Hormonal Factors in Breast Cancer. Breast cancer and hormonal contraceptives: collaborative reanalysis of individual data on 53297 women with breast cancer and 100239 women without breast cancer from 54 epidemiological studies. Lancet 1996; 347: 1713-27.

44. Beaber EF, Buist DS, Barlow WE i wsp. Recent oral contraceptive use by formulation and breast cancer risk among women 20 to 49 years of age. Cancer Res 2014; 74: 4078-89.

45. Helewa M, Lévesque $P$, Provencher D i wsp. Breast cancer, pregnancy, and breastfeeding. J Obstet Gynaecol Can 2002; 24: 164-80.

46. Brisken C. Progesterone signalling in breast cancer: a neglected hormone coming into the limelight. Nat Rev Cancer 2013; 13: 385-96.

47. Tsubaki M, Komai M, Fujimoto S i wsp. Activation of NF-KB by the RANKL/RANK system up-regulates snail and twist expressions and induces epithelial-to-mesenchymal transition in mammary tumor cell lines. J Exp Clin Cancer Res 2013; 32: 62.

48. Owen $S$, Ye L, Sanders AJ i wsp. Expression profile of receptor activator of nuclear- $\mathrm{KB}$ (RANK), RANK ligand (RANKL) and osteoprotegerin (OPG) in breast cancer. Anticancer Res 2013; 33: 199-206.

49. Konecny G, Pauletti G, Pegram M i wsp. Quantitative association between HER-2/neu and steroid hormone receptors in hormone receptor-positive primary breast cancer. J Nat Cancer Inst 2003; 95: 142-53.

50. Dowsett M, Harper-Wynne C, Boeddinghaus I i wsp. HER-2 amplification impedes the antiproliferative effects of hormone therapy in estrogen receptor-positive primary breast cancer. Cancer Res 2001; 61: 8452-58.

51. Lam L, Hu X, Aktary Z i wsp. Tamoxifen and ICI 182780 increase Bcl-2 levels and inhibit growth of breast carcinoma cells by modulating $\mathrm{PI} 3 \mathrm{~K} / \mathrm{AKT}$, ERK and IGF-1R pathways independent of ERalpha. Breast Cancer Res Treat 2009; 118: 605-21.

52. Peiró G, Adrover E, Sánchez-Teiada L i wsp. Increased insulin-like growth factor-1 receptor mRNA expression predicts poor survival in immunophenotypes of early breast carcinoma. Mod Pathol 2011; 24: 201-8.

53. Moerkens $M$, Zhang $Y$, Wester L i wsp. Epidermal growth factor receptor signalling in human breast cancer cells operates parallel to estrogen receptor a signalling and results in tamoxifen insensitive proliferation. BMC Cancer 2014; 14: 283.

54. Turner N, Pearson A, Sharpe R i wsp. FGFR1 amplification drives endocrine therapy resistance and is a therapeutic target in breast cancer. Cancer Res 2010; 70: 2085-94.

55. Giulianelli S, Cerliani JP, Lamb CA i wsp. Carcinoma-associated fibroblasts activate progesterone receptors and induce hormone independent mammary tumor growth: a role for the FGF-2/FGFR-2 axis. Int J Cancer 2008; 123: 2518-31. 